\title{
Dialektisk atferdsterapi for ungdommer med gjentatt suicidal og selvskadende adferd - en randomisert kontrollert undersøkelse
}

Ved Lars Mehlum, Anita Johanna Tørmoen, Maria Ramberg, Egil Haga, Lien My Diep, Anne Mari Sund og Berit Grøholt

\begin{abstract}
Vi undersøkte hvorvidt en forkortet versjon av dialektisk atferdsterapi tilpasset for tenåringer (DBT-A) er mer effektiv enn vanlig behandling (VB) i å redusere villet egenskade. I undersøkelsen deltok 77 ungdommer med nylig og repetert villet egenskade, tilfeldig fordelt til å motta enten DBT-A eller VB i 19 uker. Vi målte antall episoder med villet egenskade, nivå av selvmordstanker, depresjon, håpløshet og symptomer på ustabil personlighetsforstyrrelse ved behandlingsstart og etter 9, 15 og 19 uker. Vi fant at de fleste ungdommene i begge grupper fullførte behandlingen og at bruken av krisetjenester var beskjeden. De ungdommene som fikk DBT-A, rapporterte imidlertid signifikant færre episoder med villet egenskade og lavere nivå av selvmordstanker og depresjonsymptomer enn ungdommene som fikk VB. Vår konklusjon er at DBT-A er mer effektivt i å behandle ungdommer med villet egenskade enn vanlig behandling.
\end{abstract}

We examined whether a shortened form of dialectical behavior therapy (DBT-A) is more effective than enhanced usual care (EUC) to reduce self-harm in adolescents. This was a randomized study of 77 adolescents with recent and repetitive self-harm treated at community child and adolescent psychiatric outpatient clinics randomly allocated to either DBT-A or EUC. Assessments of self-harm, suicidal ideation, depression, hopelessness and symptoms of borderline personality disorder were made at baseline and after 9 , 15 and 19 weeks (end of trial period) and frequency of hospitalizations and emergencydepartment visits over the trial period were recorded. Treatment retention was generally good in both treatment conditions and the use of emergency services was low. DBT-A was superior to EUC in reducing self-harm, suicidal ideation and depressive symptoms. Effect sizes were large for treatment outcomes in patients who received DBT-A, whereas effect sizes were small for outcomes in patients receiving EUC. We conclude that DBT-A may be an effective intervention to reduce self-harm, suicidal ideation and depression and adolescents with repetitive self-harming behavior.

\section{Bakgrunn}

Villet egenskade blant ungdommer er et alvorlig og omfattende folkehelseproblem i mange land. Studier viser at mellom 5 og 10 prosent av ungdommer har skadet seg selv med vilje i løpet av det siste året, og kutting er den vanligst rapporterte metoden. Den hyppigst rapporterte årsaken som oppgis til denne adferden er å regulere eller slippe unna intenst ubehagelige følelser (Jacobson \&t Gould, 2007; Madge et al., 2008). Bare mellom 10 og 20 prosent av tenåringer som har skadet seg selv med vilje rapporterer at de har mottatt en form for behandling etterpå (Ystgaard et al., 2009). Enda færre rapporterer å ha vært i kontakt med barne- og ungdomspsykiatriske behandlingtjenester.

Blant dem som blir henvist til spesialisthelsetjenesten er det mange som dropper ut, enten på grunn av egne personlige forhold, eller på grunn av forhold ved familiene de tilhører eller de kliniske tjenestene. Villet egenskade er en sterk prediktor for senere selvmord (Owens, Horrocks, \&t House, 2002). Det er derfor sterkt behov for å utvikle effektive intervensjoner som

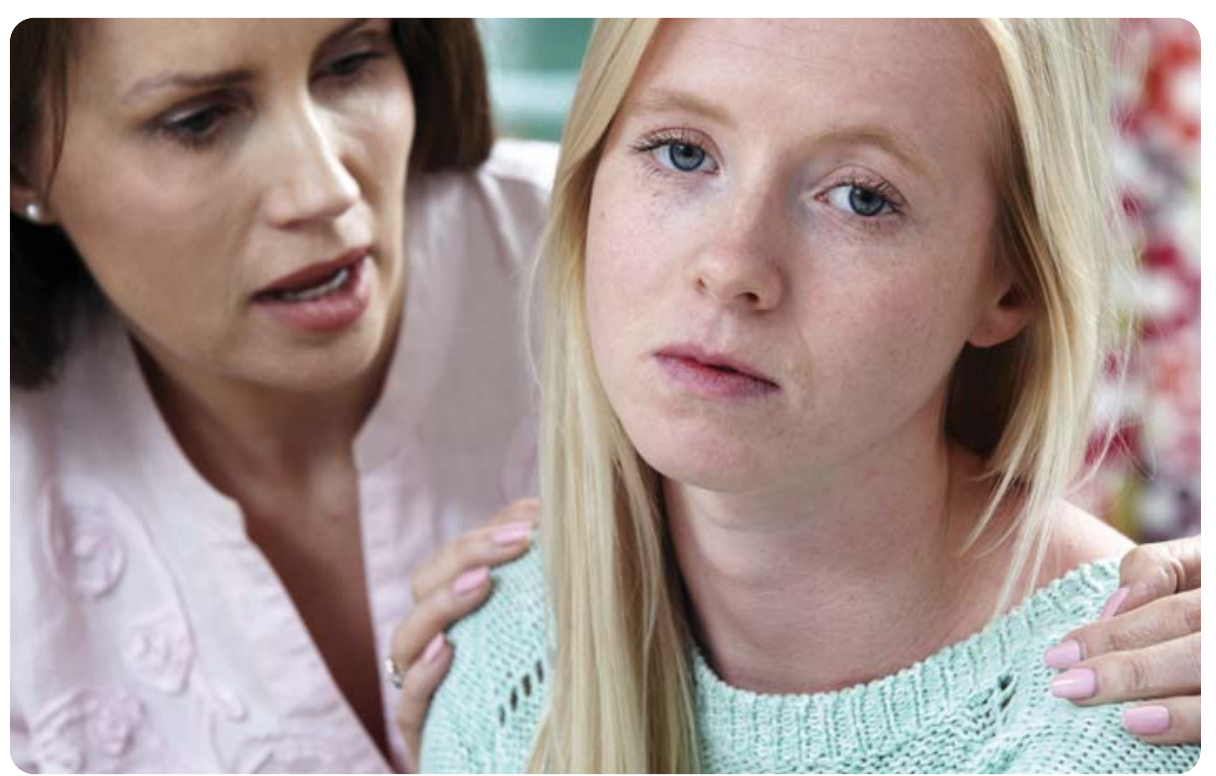

er tilgjengelige for og blir akseptert av tenåringer og deres familier, og som dessuten er gjennomførbare i praksis for klinikere i spesialisthelsetjenesten.

Gjentatt villet egenskade er svært ofte knyttet til personlighetsforstyrrelser, i særlig grad til emosjonelt ustabil personlighetsforstyrrelse (EUP). Dette er godt dokumentert i studier av voksne (Linehan, 1993). Affektiv instabilitet og en uttalt sensitivitet overfor belastninger er blant egenskaper ved personer med EUP som kan øke tendensen til suicidal og selvskadende adferd (Soloff, Lynch, Kelly, Malone, \&t Mann, 2000). Personer med EUP er ofte svært emosjonelt reaktive, reaksjonene deres har en tendens til å være ekstremt sterke, og det tar lang tid å vende tilbake til en nøytral affektiv tilstand etter en slik sterk reaksjon. Selv om klinikere og forskere hittil har diagnostisert personlighetsforstyrrelser primært hos voksne, har vi i løpet av det siste tiåret sett at stadig flere klinikerforskere har rapportert personlighetsforstyrrelser og personlighetstrekk også blant ungdommer (Miller, Muehlenkamp, \&t Jacobson, 2008). 
Slike personlighetstrekk er sterke prediktorer for personlighetsforstyrrelser i voksen alder og er assosiert med økt tendens til nedsatt funksjon, sykelighet og dødelighet over tid (Winograd, Cohen, \&t Chen, 2008). Hvorvidt behandlingsmessige intervensjoner som iverksettes i tenårene kan forebygge slik utvikling av voksen personlighetspatologi, som igjen kan være knyttet til villet egenskade-atferd, er et viktig spørsmål å få avklart.

Det er stor mangel på randomisert kontrollerte studier (RCT) av behandling for ungdommer med villet egenskade. Wood og medarbeidere (2001) utviklet en manualbasert kognitiv atferdsterapi-orientert gruppebehandling for tenåringer, og denne viste seg mer effektiv enn vanlig behandling i å redusere villet egenskade-atferd. Disse resultatene ble imidlertid ikke replikert i to påfølgende studier fra samme gruppe (Green et al., 2011; Hazell et al., 2009). I en fersk RCT har Rossouw og Fonagy (2012) vist at mentaliseringsbasert behandling for tenåringer gir sterkere reduksjon i villet egenskade og depresjon enn det vanlig behandling gjør. Med dette viktige unntaket har det imidlertid hittil ikke blitt publisert studier av behandlinger som har vist seg mer effektive enn vanlig behandling i å redusere villet egenskade blant ungdommer.

Dialektisk atferdsterapi er en prinsippstyrt, multimodal behandling som gis poliklinisk og som opprinnelig ble utviklet av Marsha Linehan (1993) for voksne kvinner med ustabil personlighetsforstyrrelse. Gjennom flere randomisert kontrollerte undersøkelser har behandlingen vist seg bedre enn sammenligningsbehandlinger i å redusere suicidal og ikke-suicidal selvskadende adferd. Det var bedre etterlevelse av behandlingen, redusert behov for kriseinnleggelser, bedre personlighetsfungering og bedret globalt og sosialt tilpasningsnivå (Carter, Willcox, Lewin, Conrad, \&t Bendit, 2010; Koons et al., 2001; Linehan, Armstrong, Suarez, Allmon, \& Heard, 1991; Linehan, Heard, \& Armstrong,
1993; Linehan et al., 2006; Pistorello, Fruzzetti, MacLane, Gallop, \&t Iversson, 2012; Verheul et al., 2003). DBT har siden blitt tilpasset av Miller og medarbeidere (Miller, Rathus, \& Linehan, 2007) til behandling av villet egenskade blant ungdommer (DBT-A) som hadde trekk fra EUP. Tilpasningen består i å forkorte behandlingen fra ett år, som er standard, til 3-5 måneder, og dessuten i å trekke inn foreldre og foresatte i ukentlige ferdighetstreningsgrupper, og endelig i å tilføre nye ferdigheter som kan være nyttige for tenåringer med emosjonell dysregulering. Flere ukontrollerte studier har antydet at DBT-A kan være mer effektiv enn vanlig behandling i å redusere villet egenskade, samtidig som behandlingen øker etterlevelse og tilfredshet hos pasientene (se Groves et al, 2011 for oversikt). Hittil har imidlertid ingen randomisert kontrollerte studier av denne tilpasningen blitt publisert. Selv om studier av voksne altså har vist gode resultater, vet vi enda ikke om en betydelig kortere og modifisert utgave av dialektisk adferdsterapi vil ha lignende positive resultater. Vår primære hypotese i denne undersøkelsen var derfor at DBT-A vil være bedre enn vanlig behandling i å redusere villet egenskade-atferd, selvmordstanker og depresjonsymptomer hos ungdommer med villet egenskade og trekk fra emosjonelt ustabil personlighetsforstyrrelse.

\section{Metoder}

Dette var en enkeltblindet randomisert kontrollert undersøkelse som sammenlignet DBT-A med forsterket vanlig behandling (VB). Deltakerne ble tilfeldig fordelt (randomisert) (figur 1) til å motta en av behandlingene ved en av de deltakende barne- og ungdomspsykiatriske poliklinikkene.

\section{Deltakere}

Deltakerne var 77 tenåringer i alderen 12-18 år som ble rekruttert fra barneog ungdomspsykiatriske poliklinikker i Oslo og Akershus. Poliklinikkene screenet nyhenviste pasienter for nylig villet egenskade-atferd (se egen artikkel om dette i dette nummeret av Suicidologi). Ved positiv screen, ble pasienten og de foresatte invitert til et diagnostisk intervju, der de gjenværende inklusjonskriteriene ble sjekket. Diagnostiske vurderinger ble utført av erfarne klinikere som var blinde for hvilken behandling pasientene ble fordelt til. Inklusjonskriteriene var: minst to tidligere episoder av villet egenskade, der minst én hadde inntruffet i løpet av de siste 16 ukene, minst to kriterier oppfylt på DSM-IV ustabil personlighetsforstyrrelse (pluss kriterium 5; selvdestruktiv adferd), eller alternativt minst ett kriterium av DSM-IV ustabil personlighetsforstyrrelse, pluss minst to kriterier under terskelnivå. Pasientene måtte også kunne beherske norsk. Eksklusjonskriterier var bipolar lidelse (unntatt bipolar 2), schizofreni, schizo-affektiv lidelse, psykotisk lidelse ikke nærmere angitt, IQ lavere enn 70 og Asperger syndrom. Villet egenskade ble definert som forgiftning eller selvskade uavhengig av intensjon (Hawton, Rodham, Evans, \& Weatherall, 2002), noe som omfattet villet egenskade med suicidal intensjon, selvskading og villet egenskadeepisoder med uklar intensjon. Fra mars 2008 til mars 2012 ble i alt 152 tenåringer som hadde positiv screen rekruttert fra de deltakende barne- og ungdomspsykiatriske poliklinikkene, samt ytterligere 142 tenåringer som ble direkte henvist til studien fra allmennleger, barnevern eller skolehelsetjeneste. Disse ble først sjekket for inklusjonskriterier (figur 1), og av disse ble 97 vurdert ved intervju. Av disse ble til slutt 77 tenåringer inkludert i studien og randomisert.

\section{Behandling og behandlere}

Pasientene mottok enten DBT eller VB av behandlere som arbeidet ved og ble lønnet av en av de ti barne- og ungdomspsykiatriske poliklinikkene som deltok i studien. Behandlerne ga enten DBT eller VB, ingen behandlere ga begge deler. Pasientene mottok ikke-manualisert farmakoterapi etter behov. 
Figur 1. Flytdiagram (CONSORT) for deltagerne i den randomiserte studien som sammenligner dialektisk atferdsterapi tilpasset tenåringer med vanlig behandling for suicidal og selvskadende atferd.

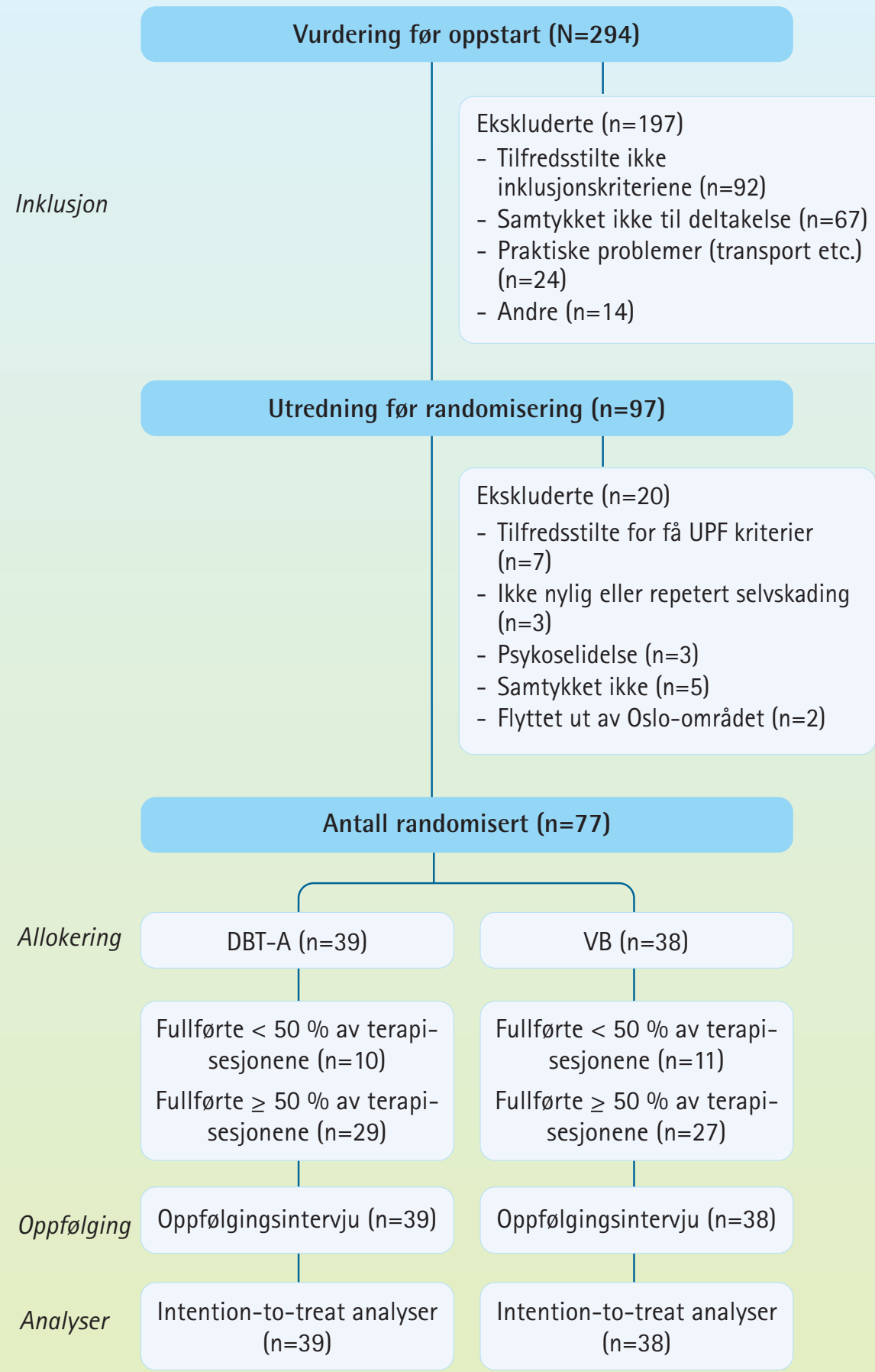

Forkortelser:

CONSORT - Consolidated Standards of Reporting Trials

UPF - Ustabil personlighetsforstyrrelse, DBT-A - Dialektisk atferdsterapi tilpasset tenåringer VB - Vanlig behandling.

\section{Dialektisk atferdsterapi}

Dialektisk atferdsterapi ble gitt i 19 uker og bestod av en ukentlig sesjon med individualterapi (60 minutter), en ukentlig sesjon med flerfamilie ferdighetstrening (120 minutter) og familieterapisesjoner og telefonkonsultasjoner med individualterapeut utenfor terapitimene etter behov. Femten psykologer og psykiatere som tidligere var ukjent med DBT ble rekruttert i forbindelse med studien og ble opplært gjennom et 80 timers seminar, samt derpå følgende 12 måneder med veiledet praksis i metoden. Terapeutene ble sjekket for adherens til DBT-A-behandlingsprinsippene. Av de rekrutterte kandidatene ble 8 terapeuter $(2$ psykiatere, 5 kliniske psykologer og 1 spesialist i pedagogisk-psykologisk rådgivning) valgt ut etter å ha vist seg som adherente til behandlingsmetoden i minst ett behandlingsforløp. Adherens ble definert som konsistent over nivået på 4,0 på en skala spesielt utviklet for formålet. Adherens til DBT-prinsipper ble sjekket for den enkelte terapeut gjennom hele studien.

\section{Vanlig behandling (VB)}

Vanlig behandling var 19 uker med standard behandling (forsterket i forbindelse med studien ved å kreve at terapeuten samtykket til å gi i gjennomsnitt en ukentlig behandlingstime per pasient i minst 19 uker) gitt av terapeuter (4 psykiatere, 16 kliniske psykologer, 6 kliniske sosionomer, 2 kliniske pedagoger, 1 psykiatrisk sykepleier og 1 psykologistudent) som ikke var opplært i DBT og dermed ikke praktiserte DBT. VB var ikke manualisert og ble ikke sjekket for adherens, men var enten psykodynamisk orientert terapi eller kognitiv atferdsterapi kombinert med psykofarmakologisk behandling etter behov. VB ble gitt i minst 19 uker, men kunne vare utover denne perioden avhengig av terapeutenes vurdering av sine pasienters behov. 


\section{Pasientsikkerhet}

Studien var designet til å tilfredsstille anbefalingene fra National Institute of Mental Health (NIMH) (Pearson, Stanley, King, \&t Fisher, 2001) for intervensjonsforskning med pasienter med høy risiko for suicidalitet. Alle terapeutene i studien mottok opplæring i selvmordsrisikovurdering og intervensjon før pasientbehandlingen startet. For begge pasientgruppene ble resultater fra startevalueringene gjort tilgjengelig for pasientenes terapeuter før den første terapitimen. Hvis en pasients oppfølgningsdata viste at det kunne være høy risiko for villet egenskade eller selvmord, tok prosjektledelsen umiddelbart kontakt med pasientens terapeut.

Studien var godkjent av REK Sør-øst, og alle pasienter og foresatte gav skriftlig informert samtykke.

\section{Vurderinger}

Vurderinger ble utført gjennom intervju og selvutfylling ved oppstart og før randomisering, gjennom uavhengige intervjuere som var blinde for hvilken behandling den enkelte var fordelt til. Selvutfylte data ble innsamlet på nytt etter 9 og 15 uker, og både selvutfylte og intervjubaserte data ble innsamlet ved behandlingslutt etter 19 uker. Detaljer om hvilke målemetoder som ble benyttet er beskrevet separat (Mehlum et al., 2014). Studiedeltakerne mottok et mindre pengebeløp som kompensasjon for hver vurderingssesjon.

\section{Utfallsmål}

De primære utfallsmålene var som følger: antall selvrapporterte selvskadingsepisoder i løpet av behandlingsperioden (selvmordsforsøk og ikke-suicidal selvskading sett under ett), alvorsgrad av selvmordstanker og depresjonssymptomer gjennom behandlingsperioden. Andre utfallsmål var håpløshet, borderline-symptomer og innleggelser og kontakt med legevakt på grunn av villet egenskade-adferd i løpet av behandlingsperioden. Detaljer om disse utfallsmålene er rapportert annetsteds (Mehlum et al., 2014).

\section{Målinger og målingsintegritet}

To barne- og ungdomspsykiatere og to andre klinikere som var blinde for hvilken behandling hver enkelt ble fordelt til, utførte intervjuene før behandlingsstart. Ti uavhengige ratere som også var blinde for hvilken behandling den enkelte fikk og for målingene ved behandlingsstart, utførte intervjuene ved behandlingsslutt. For å opprettholde blindingen utførte en ikke-blindet prosjektkoordinator alle de praktiske oppgavene i forbindelse med oppfølgningsintervjuene og samlet opplysninger om behandlingshistorien. Alle pasientene ble instruert til å ikke avsløre noen informasjon om hvilken behandling de hadde mottatt. Alle intervjuer ble tatt opp på lydbånd og interskårer-reliabilitet (IRR) av diagnoser, og utfallsvariabler ble undersøkt av en barne-og ungdomspsykiater (AMS) som var ekspert på de relevante vurderingsinstrumentene. Basert på 26 IRR-vurderte intervjuer, ble dikotome variabler testet med $k$ og kontinuerlige variabler testet med intraklasse-korrelasjon (ICC), og alle testene viste akseptabel reliabilitet av de utførte målingene.

\section{Statistiske analyser}

Vi benyttet Intention-to-treat-prinsipper for data-analysene. Gjennomsnitt og standardavvik, eller median og interquartile range, ble regnet ut for normalfordelte og ikke-normalfordelte variabler. Forskjeller mellom sentraltendens i gruppene ble testet med T-test eller Mann-Whitney U-test. Kategoriske variabler ble sammenlignet ved hjelp av kjikvadrat eller Fisher eksakt test. Estimering av trender og forskjeller mellom gruppetrender over tid ble undersøkt ved hjelp av mixed-effects multiple regression, med sumskårer som avhengige variabler. Repetisjon av villet egenskade over behandlingsperioden ble undersøkt ved hjelp GEE-statistikk (Generalized Estimating Equation) med Poisson og robust varians. Mediasjonsanalyser ble utført ved hjelp av SEM (Structural Equation Modelling) for utfall med normalfordeling og GSEM (Generalized SEM) for tellevariabler. Analyser ble utført ved hjelp av STATA 13 (STATA, 2011) og IBM SPSS 20.0 (IBM, 2012).

\section{Resultater \\ Utvalgskarakteristika}

I alt ble 77 ungdommer fordelt til enten DBT-A $(n=39)$ eller VB $(n=38)$ slik som vist i figur 1 . Selv om noen av pasientene droppet ut av behandlingen, ble alle fulgt fra behandlingsstart til behandlingsslutt i forskningsprosjektet. Demografiske karakteristika ved behandlingsstart, diagnoser og informasjon om suicidal og ikkesuicidal villet egenskade-atferd er vist i tabell 1. Det var ingen statistisk signifikante forskjeller mellom de to gruppene på noe mål ved behandlingsstart.

\section{Behandling}

I løpet av behandlingsperioden deltok DBT-A-pasientene gjennomsnittlig i 13.8 $(\mathrm{SD}=6.9)$ individualterapisesjoner, 11.2 $(\mathrm{SD}=5.9)$ ferdighetstreningsgruppesesjoner, $2.6(S D=2.2)$ familieterapisesjoner og 3.3 (SD = 4.5) korte telefonsamtaler mellom behandlingssesjonene. Tilsvarende tall for VB-pasientene var $11.5(\mathrm{SD}=6.4)$ individualsesjoner, $0.5(S D=2.1)$ gruppeterapisesjoner, $5.8(\mathrm{SD}=9.8)$ familieterapisesjoner og $3.5(S D=4.4)$ telefonsesjoner. Med unntak av gruppesesjonene, var det ingen statistisk signifikante intergruppeforskjeller når det gjelder antall behandlingssesjoner som pasientene deltok i. Det gjennomsnittlige antallet uker som pasientene mottok noen behandling var $14.9(\mathrm{SD}=5.6)$ for DBT-A-pasientene og 12.9 (SD = 5.1) for VB-pasientene. I DBT-A er det å være borte mer enn 3 individualterapisesjoner betraktet som dropout. I forhold til dette kriteriet var det 10 pasienter $(25.6 \%)$ som droppet ut. I VB-gruppen, hvor slike strenge dropout-regler ikke ble anvendt, var det 11 pasienter (28.9\%) som deltok i mindre enn $50 \%$ av de ukentlige individualterapisesjonene. 
Tabell 1. Demografiske og diagnostiske data samt antall selvmordsforsøk og selvskadingsepisoder ved oppstart av behandling for tenåringer $(\mathrm{N}=77)$ fordelt til 19 ukers behandling med dialektisk atferdsterapi eller vanlig behandling.

\begin{tabular}{|c|c|c|c|c|c|c|}
\hline \multirow[t]{2}{*}{ Variabel $^{\mathrm{a}}$} & \multicolumn{2}{|c|}{$\begin{array}{l}\text { Dialektisk } \\
\text { atferdsterapi } \\
\quad(n=39)\end{array}$} & \multicolumn{2}{|c|}{$\begin{array}{c}\text { Vanlig } \\
\text { behandling } \\
n=(38)\end{array}$} & \multicolumn{2}{|c|}{$\begin{array}{c}\text { Hele } \\
\text { utvalget } \\
n=(77)\end{array}$} \\
\hline & $n$ & $\%^{b}$ & $n$ & $\%^{b}$ & $n$ & $\%$ \\
\hline Jente & 34 & 87.2 & 34 & 89.5 & 68 & 88.3 \\
\hline Etnisk norsk & 30 & 78.9 & 32 & 91.4 & 62 & 84.9 \\
\hline Videregående skole & 15 & 39.5 & 12 & 32.4 & 27 & 36.0 \\
\hline Gifte foreldre & 17 & 43.6 & 17 & 44.7 & 34 & 44.2 \\
\hline Barnevern (nåværende) & 6 & 15.4 & 7 & 18.4 & 13 & 16.9 \\
\hline Barnevern (tidligere) & 10 & 26.3 & 11 & 28.9 & 21 & 27.6 \\
\hline Tidligere psykiatrisk behandling & 28 & 73.7 & 23 & 62.2 & 51 & 68.0 \\
\hline Bruk av psykofarmaka (tidligere) & 2 & 5.4 & 6 & 17.1 & 8 & 11.1 \\
\hline Bruk av psykofarmaka (nåværende) & 6 & 15.4 & 3 & 7.9 & 9 & 11.7 \\
\hline \multicolumn{7}{|l|}{ DSM-IV Akse I og II diagnoser } \\
\hline -Alvorlig depresjon & 9 & 23.1 & 8 & 21.1 & 17 & 22.1 \\
\hline -Annen depressiv lidelse & 16 & 41.0 & 13 & 34.2 & 29 & 37.7 \\
\hline -Panikkangst & 2 & 5.1 & 5 & 13.2 & 7 & 9.1 \\
\hline -Posttraumatisk stress forstyrrelse & 7 & 17.9 & 6 & 15.8 & 13 & 16.9 \\
\hline -Angstlidelse & 18 & 46.2 & 15 & 39.5 & 33 & 42.9 \\
\hline -Misbruks/avhengighetslidelse & 1 & 2.6 & 1 & 2.6 & 2 & 2.6 \\
\hline -Spiseforstyrrelse & 3 & 7.7 & 3 & 7.9 & 6 & 7.8 \\
\hline -Ustabil personlighetsforstyrrelse & 10 & 26.3 & 5 & 14.3 & 15 & 20.5 \\
\hline \multirow[t]{2}{*}{ Selvmordsforsøk siste 4 måneder (n) } & 11 & 28.2 & 9 & 23.7 & 20 & 26.0 \\
\hline & Gj.snitt & SD & Gj.snitt & SD & Gj.snitt & SD \\
\hline Alder (år) & 15.9 & 1.4 & 15.3 & 1.6 & 15.6 & 1.5 \\
\hline C-GAS skåre & 55.3 & 8.0 & 57.9 & 10.1 & 56.1 & 8.3 \\
\hline CBCL totalskåre, foreldreutfylt & 69.6 & 11.0 & 68.4 & 8.9 & 69.0 & 9.8 \\
\hline $\begin{array}{l}\text { Trekk fra ustabil } \\
\text { personlighetsforstyrrelse }(n)^{c}\end{array}$ & 4.0 & 2.0 & 3.0 & 3.0 & 4.0 & 2.0 \\
\hline $\begin{array}{l}\text { Nåværende } \\
\text { DSM-IV Akse I forstyrrelser }(n)^{c}\end{array}$ & 2.0 & 1.0 & 1.0 & 3.0 & 1.0 & 2.0 \\
\hline Selvmordsforsøk, livstid (n) ${ }^{d}$ & 2.1 & 5.2 & 1.3 & 2.8 & 1.7 & 4.2 \\
\hline Selvskading, livstid $(n)^{\mathrm{C}}$ & 49.5 & 159.5 & 25.0 & 45.5 & 34.0 & 88.0 \\
\hline
\end{tabular}

\footnotetext{
a Ingen signifikant forskjell mellom gruppene ved behandlingsstart.

b Små variasjoner i prosentbasis i enkelte celler på grunn av manglende data.

c Median og interquartile range.

d Medianen var null for begge grupper. Interquartile range var 1.0 i DBT-gruppen og 1.3 i VB-gruppen.

Referanse: Mehlum, L., Tormoen, A. J., Ramberg, M., Haga, E., Diep, L. M., Laberg, S., ... Grøholt, B. (2014). Dialectical behavior therapy for adolescents with repeated suicidal and self-harming behavior: a randomized trial. J Am Acad Child Adolesc Psychiatry, 53(10), 1082-1091. doi: 10.1016/j.jaac.2014.07.003
}

Tre av DBT-A-pasientene (7.7 \%) brukte minst ett psykofarmakon gjennomsnittlig i 94.7 dager $(S D=64.3)$, mens 5 VBpasienter (13.2 \%) brukte slike medikamenter gjennomsnittlig i 72.8 dager (SD = 16.6), og det var ingen statistiske forskjeller mellom gruppene i forhold til dette.

\section{Suicidal og selvskadende adferd og selvmordstanker}

Det var ingen selvmord i løpet av behandlingsperioden. Forekomsten av villet egenskade-episoder i de to behandlingsgruppene gjennom behandlingsperioden er vist i figur 2. Mens VB-pasientene rapporterte gjennomsnittlig $4.7(\mathrm{SD}=5.5)$ episoder i løpet av de første 9 ukene og 3.3 $(\mathrm{SD}=6.8)$ i løpet av de påfølgende 6 ukene, rapporterte DBT-A-pasientene gjennomsnittlig 4.1 (SD = 5.8) og 1.2 (SD $=2.0$ ) slike episoder i de korresponderende tidsintervallene. Den gjennomsnittlige reduksjonen i forekomsten av villet egenskade i DBT-A-gruppen, var sterkt signifikant $(p<0.001)$, mens fallet i VB-gruppen ikke var signifikant. Intergruppeforskjellen var statistisk signifikant ( $p=0.021)$. Begge gruppene hadde et nivå av selvmordstanker ved behandlingsstart som lå godt over det kliniske cutoff-nivået som vanligvis regnes som 31 (Reynolds \& Mazza, 1999), og begge gruppene hadde en lik reduksjon i selvmordstanker over de første 15 ukene i behandlingsperioden (figur 2 og tabell 2). Men mens nivået av selvmordstanker fortsatte å falle i DBT-A-gruppen gjennom hele behandlingsperioden, flatet det ut mot slutten av perioden for pasientene i VB-gruppen. Denne intergruppeforskjellen var statistisk signifikant.

\section{Depressive symptomer}

Begge pasientgruppene viste en signifikant reduksjon i selvrapporterte depresjonsymptomer, men bare DBT-A-gruppen viste en signifikant reduksjon i intervjuerskåret depresjon. Denne intergruppeforskjellen var statistisk signifikant (tabell 2). 
Figur 2. Sammenlikning av alvorlighetsgrad av selvmordstanker og antall villet egenskadeepisoder i løpet av behandlingsperioden for pasienter som mottok dialektisk atferdsterapi tilpasset tenåringer $(n=39)$ og vanlig behandling $(n=38)$.

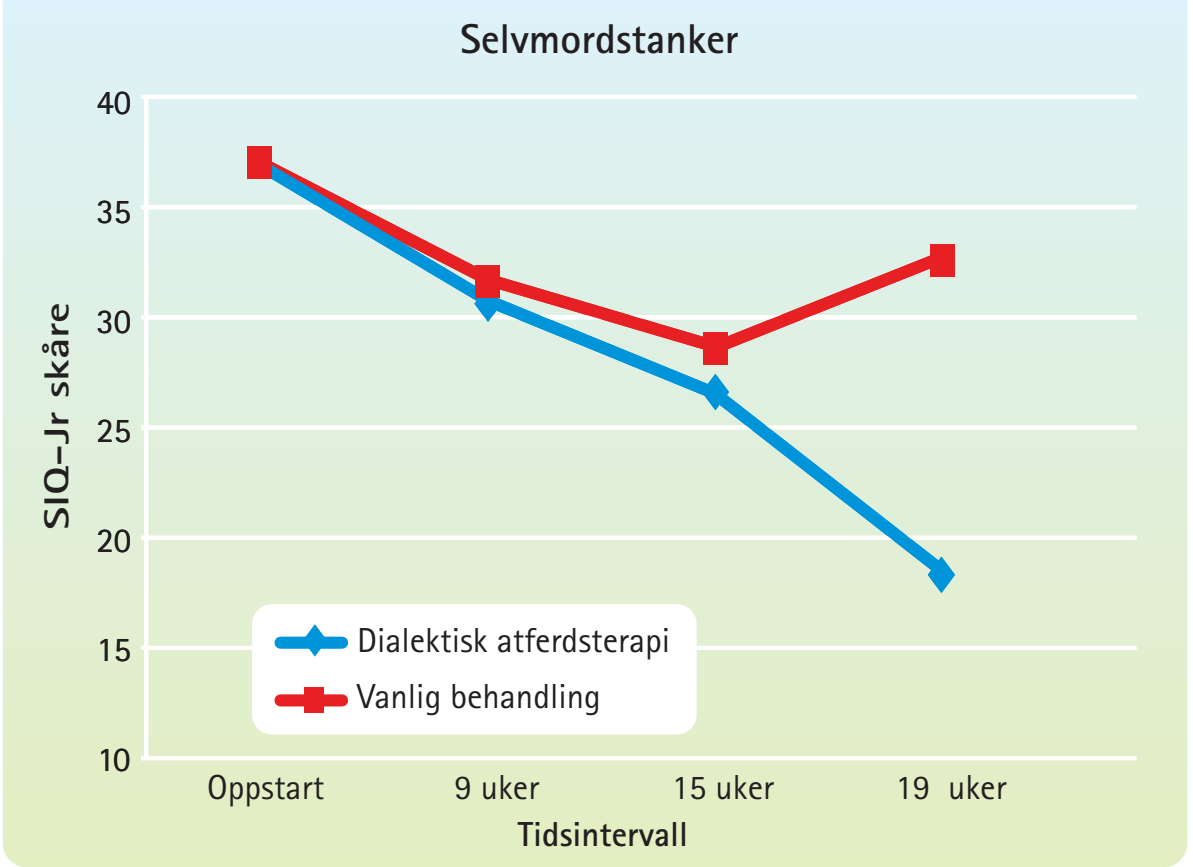

SIQ-Jr - Suicidal Ideation Questionnaire Junior version. Selvmordstanker ble målt ved oppstart, 9, 15 og 19 uker. Mixed-effects lineær regresjons analyser viste statistisk signifikant forskjell mellom gruppene i reduksjon av selvmordstanker $(\Delta$ slope $=-0.62$ pr uke, $p=0.010)$.

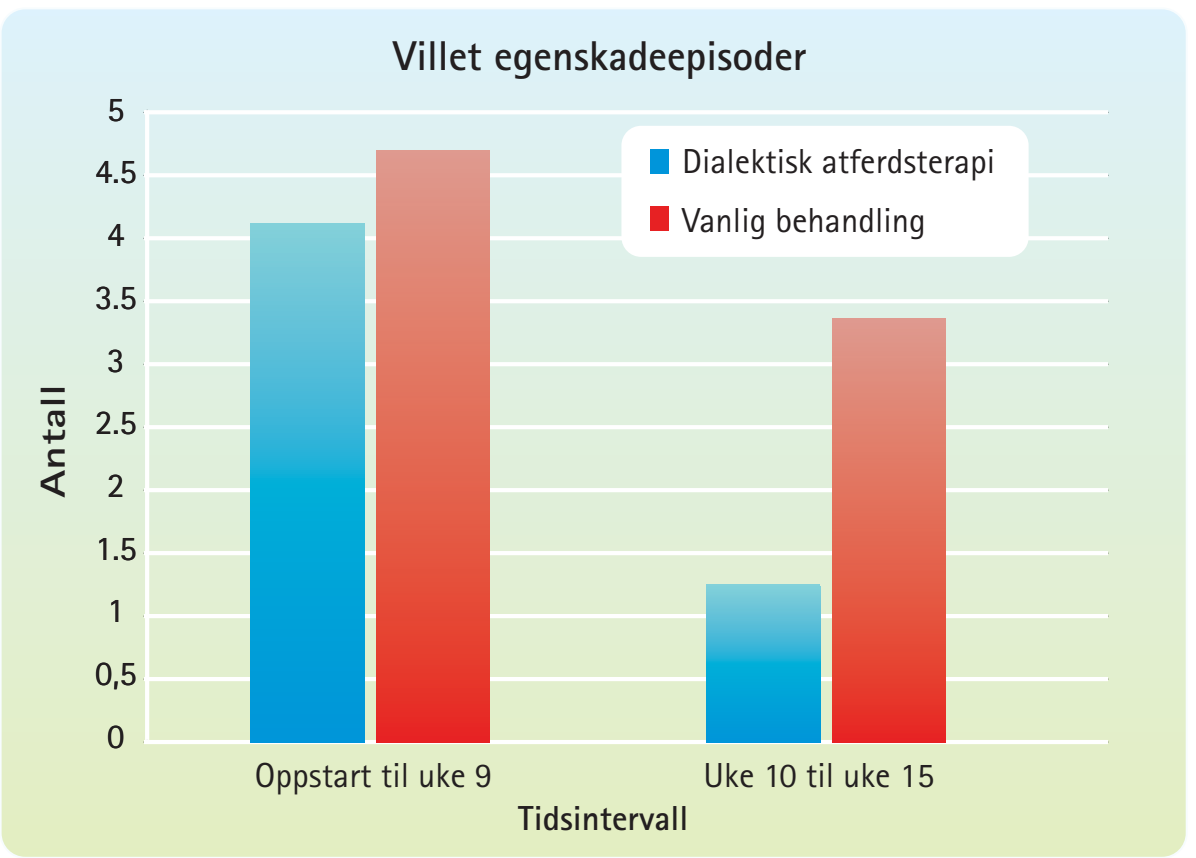

DBT-A - Dialektisk atferdsterapi tilpasset tenåringer, VB - vanlig behandling.

Antall villet egenskade episoder i løpet av studien ble sammenlignet i tidsperiodene fra oppstart til uke 9 og fra uke 10 til uke 15. Generalized estimating equation analyse med Poisson fordeling der det ble brukt exchange-able correlation structure med robust varians viste at bare DBT-A gruppen hadde signifikant reduksjon av villet egenskade. Forskjellen mellom gruppene var statistisk signifikant $(\triangle$ slope $=-0.92,95 \%$ Konfidensintervall=-1.69, $-0.15, p=0.021)$.

\section{Forholdet mellom behandlingsutfall} og behandlingsintensitet

Forskjellen i både den gjennomsnittlige varigheten av behandlingen og antall behandlingssesjoner motiverte oss til å utføre en serie med analyser for å undersøke hvorvidt disse to variablene kunne mediere forholdet mellom behandlingen og de tre primære utfallsvariablene. Totalt antall behandlingskontakter ble påvist å være en partiell mediator av sammenhengen mellom behandling og selvmordstanker, mens ingen mediasjonseffekter ble funnet for andre utfall eller for total behandlingstid.

\section{Andre utfall}

DBT-A-gruppen rapporterte reduksjoner i håpløshet og i borderline-symptomer (tabell 2), men det var ingen signifikante intergruppeforskjeller på disse utfallene. En DBT-A-pasient og to VB-pasienter ble hospitalisert på grunn av villet egenskadeatferd i løpet av behandlingsperioden. I tillegg ble to DBT-A-pasienter og 5 VBpasienter behandlet ved legevakt på grunn av villet egenskade. Disse forskjellene var ikke statistisk signifikante.

\section{Diskusjon}

Dette var den første randomisert kontrollerte studien av effekten av en forkortet versjon av dialektisk adferdsterapi tilpasset for behandling av multiproblem selvskadende tenåringer med trekk fra emosjonelt ustabil personlighetsforstyrrelse. I begge gruppene var dropout fra behandlingen beskjeden. DBT-A var imidlertid overlegen VB når det gjelder å redusere forekomst av villet egenskade, selvmordstanker og depresjonsymptomer i løpet av behandlings-perioden. Effektstørrelsene for utfall i DBT-A-gruppen var generelt store, men svake eller moderate i VB-gruppen. Interessant nok var det slik for flere utfallsmål at forskjellene mellom behandlingsgruppene økte mot slutten av behandlingsperioden; DBT-A-pasientene fortsatte bedringen, mens VB-pasientene ikke gjorde det. 
Tabell 2. Utfall for tenåringer $(\mathrm{N}=77)$ fordelt til 19 uker med Dialektisk atferdsterapi eller vanlig behandling, gruppert etter behandlingsgruppe.

\begin{tabular}{|c|c|c|c|c|c|c|c|c|c|c|}
\hline & \multicolumn{2}{|c|}{$\begin{array}{l}\text { Dialektisk } \\
\text { atferdsterapi } \\
\quad(n=39)\end{array}$} & \multirow[t]{2}{*}{$\begin{array}{l}\text { P-verdi } \\
\text { slope }\end{array}$} & \multirow[t]{2}{*}{$\begin{array}{c}\text { Effekt } \\
\text { størrelse }^{a}\end{array}$} & \multicolumn{2}{|c|}{$\begin{array}{l}\text { Vanlig } \\
\text { behandling } \\
\quad(n=38)\end{array}$} & \multirow[t]{2}{*}{$\begin{array}{l}\text { P-verdi } \\
\text { slope }\end{array}$} & \multirow[t]{2}{*}{$\begin{array}{c}\text { Effekt } \\
\text { størrelse }^{a}\end{array}$} & \multirow[t]{2}{*}{ slope $^{b}$} & \multirow[t]{2}{*}{$\begin{array}{l}\text { P-verdi } \\
\triangle \text { slope }\end{array}$} \\
\hline & Gj.snitt & SD & & & Gj.snitt & SD & & & & \\
\hline \multicolumn{11}{|c|}{ Selvmordstanker (SIQ-Jr') } \\
\hline Oppstart & 36.91 & 20.82 & $<0.001$ & 0.89 & 36.91 & 26.73 & 0.101 & 0.16 & -0.62 & 0.010 \\
\hline 9 uker & 30.72 & 17.53 & & & 31.71 & 21.20 & & & & \\
\hline 15 uker & 26.58 & 13.55 & & & 28.53 & 20.97 & & & & \\
\hline 19 uker & 18.30 & 11.11 & & & 32.56 & 23.99 & & & & \\
\hline \multicolumn{11}{|l|}{ Håpløshet $\left(\mathrm{BHS}^{\mathrm{C}}\right)$} \\
\hline Oppstart & 11.48 & 5.41 & $<0.001$ & 0.97 & 10.35 & 5.81 & 0.072 & 0.22 & -0.13 & 0.071 \\
\hline 9 uker & 10.43 & 5.80 & & & 10.00 & 6.13 & & & & \\
\hline 15 uker & 10.33 & 5.88 & & & 8.48 & 6.20 & & & & \\
\hline 19 uker & 6.23 & 5.30 & & & 9.06 & 6.53 & & & & \\
\hline \multicolumn{11}{|l|}{ Depresjon $\left(\mathrm{SMFO}^{\mathrm{C}}\right.$ ) } \\
\hline Baseline & 14.92 & 5.35 & $<0.001$ & 0.88 & 15.11 & 6.23 & 0.012 & 0.41 & -0.10 & 0.179 \\
\hline 9 uker & 12.87 & 6.17 & & & 13.39 & 5.60 & & & & \\
\hline 15 uker & 12.77 & 6.31 & & & 12.23 & 5.85 & & & & \\
\hline 19 uker & 10.19 & 5.04 & & & 12.58 & 6.62 & & & & \\
\hline \multicolumn{11}{|c|}{ Depresjon (MADRS ${ }^{\mathrm{C}}$ ) } \\
\hline Oppstart & 19.03 & 7.84 & $<0.001$ & 0.86 & 17.50 & 7.13 & 0.075 & 0.24 & -0.22 & 0.019 \\
\hline 19 uker & 12.29 & 7.52 & & & 15.76 & 8.14 & & & & \\
\hline \multicolumn{11}{|c|}{$\begin{array}{l}\text { Symptomer på ustabil } \\
\text { personlighetsforstyrrelse } \\
\left(B S L^{C}\right)\end{array}$} \\
\hline Oppstart & 38.47 & 19.32 & $<0.001$ & 0.89 & 40.18 & 21.66 & 0.061 & 0.25 & -0.50 & 0.050 \\
\hline 9 uker & 33.63 & 17.35 & & & 34.94 & 18.57 & & & & \\
\hline 15 uker & 33.85 & 20.04 & & & 33.67 & 21.28 & & & & \\
\hline 19 uker & 21.34 & 14.38 & & & 34.75 & 22.15 & & & & \\
\hline
\end{tabular}

\footnotetext{
a Gjennomsnittlig bedring fra oppstart til 19 uker delt på standard avvik ved oppstart. Alle effektstørrelser har positive verdier.

b Estimat av forskjeller i slope (pr uke). c Detaljer om hvilke utfallsmål som ble brukt er publisert annetsteds (Mehlum et al., 2014)
}

Referanse: Mehlum, L., Tormoen, A. J., Ramberg, M., Haga, E., Diep, L. M., Laberg, S., . . Grøholt, B. (2014). Dialectical behavior therapy for adolescents with repeated suicidal and self-harming behavior: a randomized trial. J Am Acad Child Adolesc Psychiatry, 53(10), 1082-1091. doi: 10.1016/j.jaac.2014.07.003

Tidligere DBT-studier blant voksne har pekt på at det å lære bort spesifikke ferdigheter kan være en viktig faktor i å få redusert villet egenskade og depresjon (Neacsiu, Rizvi, \& Linehan, 2010). Tidlig monitorering og eksplisitt fokus på villet egenskade-atferd gjennom de 19 ukene med behandling kan for DBT-A-pasientene også ha representert en viktig behandlingskomponent.

Det var heldigvis ingen selvmord blant noen av pasientene og totalt sett var det få pasienter som ble innlagt eller tilsett ved legevakt, selv om det var en nonsignifikant trend at DBT-A-pasientene hadde flere legevaktbesøk.

Til tross for at villet egenskade blant tenåringer er høyfrekvent i befolkningen, har det hittil vært lite evidens for effektive behandlingsmetoder. Tenåringer med emosjonelt ustabile personlighetstrekk og gjentatt villet egenskade har vanligvis blitt betraktet som en vanskelig gruppe å behandle, både på grunn av sin mot- villighet til å motta behandling og sin tendens til tidlig dropout, og på grunn av pasientsikkerhetsproblemer. Denne første randomisert kontrollerte studien av DBT-A peker på at det faktisk er mulig å engasjere tenåringer i slik behandling, beholde dem i behandlingen og få effekter, samtidig som pasientsikkerheten opprettholdes. Bare mentaliseringsbasert behandling (MBT-A) (Rossouw \&t Fonagy, 2012) har hittil demonstrert lignende resultater. 
Men fra en pragmatisk og økonomisk synsvinkel er en viktig forskjell mellom disse behandlingene at MBT-A tar 3 ganger så lang tid (1 år versus 4 måneder). I det begrensede tidsrommet som behandlingsperioden varte kunne vi ikke påvise noen signifikante gruppeforskjeller når det gjelder intensitet av borderlinesymptomer. Oppfølgingsstudier er påkrevd for å få avklart om slike forskjeller kan oppstå på sikt.

All behandling i denne studien ble utført av vanlige barne- og ungdomspsykiatriske poliklinikker, og behandlingen var gratis for familiene. Vårt pasientmateriale var derfor trolig mindre sosialt skjevt enn i studier som har vært utført i andre land og kontekster. Dette styrker den eksterne validiteten av funnene i forhold til tilsvarende urbane behandlingssettinger. Både DBT-A-individualterapisesjonene og ferdighetstrenings-gruppesesjonene ble levert med tilstrekkelig høy adherens, noe som viser at DBT-A kan gis på høyt nok nivå i en vanlig poliklinisk behandlingssetting og ikke bare av eksperter med mange års erfaring i bruk av DBT.

Selv om disse funnene er lovende, har denne studien flere viktige begrensninger. Studien hadde adekvat statistisk styrke, men utvalgsstørrelsen var likevel for-holdsvis liten og funnene bør derfor tolkes med varsomhet. Kontrollbehandlingen VB var ikke en manualbasert behandling, og VBterapeutene ble ikke sjekket for kvalitet på den behandlingen de leverte. Bare DBTA-pasienter mottok ferdighetstreningsgruppebehandling, og dette medførte en betydelig forskjell $\mathrm{i}$ behandlingsintensitet mellom de to gruppene. Selv om våre analyser ga få indikasjoner på at behandlingsintensitet hadde en medierende effekt på forholdet mellom behandling og utfall, kan vi ikke helt utelukke at denne faktoren kan ha betydning. Som i de fleste studier av villet egenskadebehandling var pasientutvalget hovedsakelig bestående av jenter, og utvalget var for lite til å kunne studere kjønnsforskjeller når det gjelder behandlingsutfall.

Blant studiens sterke sider var det fullstendige fraværet av dropout fra forskningen, anvendelse av strenge pro- sedyrer for datainnsamling, god kvalitet på målinger og på blinding og uavhengighet av skårere. De liberale inklusjonskriteriene som ble anvendt og at behandlingen ble gitt i en vanlig barne- og ungdomspsykiatrisk setting med pasienter som ble rekruttert fra et definert opptaksområde, er alle sider ved studien som styrker den eksterne validiteten av funnene.

Det er behov for nye studier som kan replikere disse funnene, og slike studier bør helst ha større utvalg og langtids oppfølgningsevaluering. Spørsmål som gjenstår å besvare er hvilke elementer i DBT-A som er de viktigste og mest effektive, hvorfor og hvordan behandlingen virker, og hvorvidt det å fokusere på spesifikke symptomer og problemer (slik som villet egenskade og selvmordstanker) heller enn et vidt spekter av atferd blant ungdommer med mange problemer vil være det mest effektive.

En utvidet utgave av denne artikkelen er tidligere publisert på engelsk (Mehlum et al., 2014)

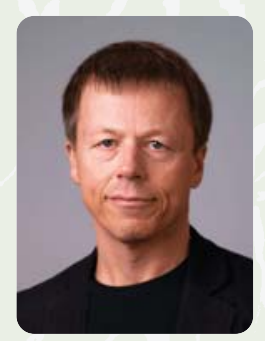

\section{Lars Mehlum} er psykiater og professor i psykiatri og suicidologi ved Universitetet i Oslo. Han er leder for NSSF og flere av senterets forskningsprosjekter, bl.a. Selvskadingsstudien. Han er DBT-Iærer og leder for NSSFs utdanningsprogram i Dialektisk Atferdsterapi.

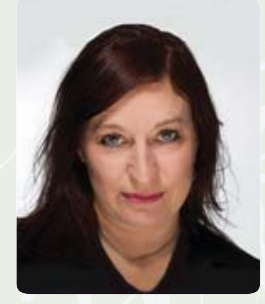

Anita Johanna Tørmoen er forsker og DBTlærer ved NSSF.

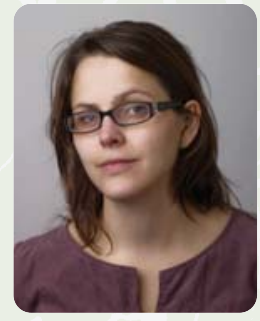

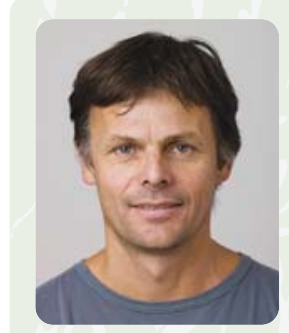

Egil Haga

er dr. philos og prosjektkoordinator for Selvskadingsstudien ved NSSF.

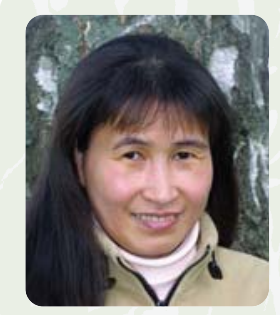

Lien My Diep

er cand scient. Hun er biostatistiker ved Oslo Senter for Biostatistikk og epidemology (OUS) og har en bistilling ved NSFF.

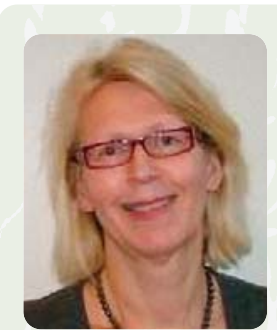

\section{Anne Mari Sund} er overlege ved St. Olavs Hospital, Trondheim og professor i barne- og ungdomspsykiatri ved NTNU. Hun forsker innenfor områdene affektive vansker, selvmordsatferd, tilknytning og forbygging av angst og depresjon hos barn.

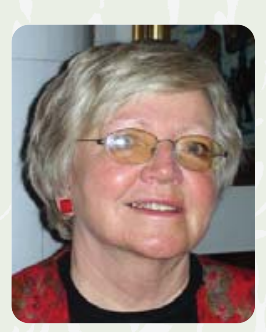

Berit Grøholt

er professor emeritus og har publisert artikler innenen rekke barnepsykiatriske emner. Hun er i dag tilknyttet Institutt for klinisk medisin og NSSF.

\section{Referanser}

Carter, G. L., Willcox, C. H., Lewin, T. J., Conrad, A. M., \&t Bendit, N. (2010). Hunter DBT project: randomized controlled trial of dialectical behaviour therapy in women with borderline personality disorder. Aust.N.Z.J.Psychiatry, 44(2), 162-173.

Green, J. M., Wood, A. J., Kerfoot, M. J., Trainor, G., Roberts, C., Rothwell, J., ... Harrington, R. (2011). Group therapy for adolescents with repeated self harm: randomised controlled trial with economic evaluation. BMJ, 342, d682.

Groves, S., Backer, H.S., van den Bosch, W., Miller, A.L. (2011). Dialectical behaviour therapy with adolescents: A review. Child and Adolescent Mental Health, 17(2), 11.

Hawton, K., Rodham, K., Evans, E., \& Weatherall, R. (2002). Deliberate self harm in adolescents: self report survey in schools in England. BMJ, 325(7374), 1207-1211. 
Hazell, P. L., Martin, G., McGill, K., Kay, T., Wood, A., Trainor, G., \&t Harrington, R. (2009). Group therapy for repeated deliberate self-harm in adolescents: failure of replication of a randomized trial. J.Am.Acad.Child Adolesc.Psychiatry, 48(6), 662-670. IBM. (2012). IBM SPSS Statistics for Windows (Version 20.0). Armonk, NY: IBM Corporation.

Jacobson, C. M., \&t Gould, M. (2007). The epidemiology and phenomenology of non-suicidal self-injurious behavior among adolescents: a critical review of the literature. Arch Suicide Res 11(2), 129-147. doi: 10.1080/13811110701247602

Koons, C. R., Robins, C. J., Tweed, J. L., Lynch, T. R., Gonzalez, A. M., Morse, J. Q., ... Bastian, L. A. (2001). Efficacy of dialectical behavior therapy in women veterans with borderline personality disorder. Behavior Therapy, 32, 371-390.

Linehan, M. M., Armstrong, H. E., Suarez, A., Allmon, D., \& Heard, H. L. (1991). Cognitive-behavioral treatment of chronically parasuicidal borderline patients. Arch.Gen.Psychiatry, 48(12), 1060-1064

Linehan, M. M., Heard, H. L., \& Armstrong, H. E. (1993). Naturalistic follow-up of a behavioral treatment for chronically parasuicidal borderline patients. Arch Gen Psychiatry, 50(12), 971-974.

Linehan, Marsha M. (1993). Cognitive-behavioral treatment of borderline personality disorder. New York: Guilford Press.

Linehan, Marsha M., Comtois, Katherine Anne, Murray Angela M., Brown, Milton Z., Gallop, Robert J., Heard Heidi L., ... Lindenboim, Noam. (2006).

Two-Year Randomized Controlled Trial and Followup of Dialectical Behavior Therapy vs Therapy by Experts for Suicidal Behaviors and Borderline Personality Disorder. Arch Gen Psychiatry, 63(7) 757-766.
Madge, N., Hewitt, A., Hawton, K., de Wilde, E. J., Corcoran, P., Fekete, S., ... Ystgaard, M. (2008). Deliberate self-harm within an internationa community sample of young people: comparative findings from the Child and Adolescent Selfharm in Europe (CASE) Study. J Child Psychol Psychiatry, 49(6), 667-677. doi: 10.1111/j.14697610.2008.01879.x

Mehlum, L., Tormoen, A. J., Ramberg, M., Haga, E., Diep, L. M., Laberg, S., ... Groholt, B. (2014). Dialectical Behavior Therapy for Adolescents With Repeated Suicidal and Self-harming Behavior: A Randomized Trial. J Am Acad Child Adolesc Psychiatry, 53(10), 1082-1091. doi: 10.1016/ j.jaac.2014.07.003

Miller, A. L., Muehlenkamp, J. J., \&t Jacobson, C. M. (2008). Fact or fiction: diagnosing borderline personality disorder in adolescents. Clin Psychol Rev, 28(6), 969-981. doi: 10.1016/j.cpr.2008.02.004

Miller, A. L., Rathus, J. H., \&t Linehan, M. M. (2007). Dialectical Behavior Therapy with Suicidal Adolescents. New York: Guilford.

Neacsiu, A. D., Rizvi, S. L, \& Linehan, M. M. (2010). Dialectical behavior therapy skills use as a mediator and outcome of treatment for borderline personality disorder. Behav.Res.Ther, 48(9), 832-839.

Owens, D., Horrocks, J., \& House, A. (2002). Fatal and non-fatal repetition of self-harm. Systematic review. Br J Psychiatry, 181, 193-199.

Pearson, J. L., Stanley, B., King, C., \&t Fisher, C. (2001). Issues to Consider in Intervention Research with Persons at High Risk for Suicidality (pp. 1-19): NIMH.

Pistorello, J., Fruzzetti, A.E., MacLane, C., Gallop, R. J., \&t Iversson, K.M. (2012). Dialectical Behavior Therapy (DBT) Applied to College Students: A Randomized Clinical Trial. J Consult Clin Psychol, $80(6), 8$
Reynolds, W. M., \&t Mazza, J. J. (1999). Assessment of suicidal ideation in inner-city children and young adolescents: Reliability and validity of the suicidal ideation questionnaire-JR. School Psychology Review, 28(1), 17-30.

Rossouw, T. I., \&t Fonagy, P. (2012). Mentalizationbased treatment for self-harm in adolescents: a randomized controlled trial. J Am Acad Child Adolesc Psychiatry, 51(12), 1304-1313 e1303.

Soloff, P. H., Lynch, K. G., Kelly, T. M., Malone, K. M., \&t Mann, J. J. (2000). Characteristics of suicide attempts of patients with major depressive episode and borderline personality disorder: a comparative study. Am J Psychiatry, 157, 601-608.

STATA. (2011). STATA Statistical Software. College Station, Tx: Stata Corporation LP.

Verheul, R., Van Den Bosch, L. M., Koeter, M. W., De Ridder, M. A Stijnen, T \& Van Den, Brink W. (2003). Dialectical behaviour therapy for women with borderline personality disorder: 12-month, randomised clinical trial in The Netherlands. $\mathrm{Br}$. Psychiatry, 182, 135-140.

Winograd, G., Cohen, P., \& Chen, H. (2008). Adolescent borderline symptoms in the community: prognosis for functioning over 20 years. J Child Psychol Psychiatry, 49(9), 933-941. doi: 10.1111/ j.1469-7610.2008.01930.x

Wood, A.,Trainor, G., Rothwell, J., Moore, A., \&t Harrington, R. (2001). Randomized trial of group therapy for repeated deliberate self-harm in adolescents. J Am Acad.Child Adolesc.Psychiatry, 40(11), 1246-1253.

Ystgaard, M., Arensman, E., Hawton, K., Madge N., van, Heeringen K., Hewitt, A., ... Fekete, S. (2009). Deliberate self-harm in adolescents: comparison between those who receive help following self-harm and those who do not. Adolesc, 32(4), 875-891.

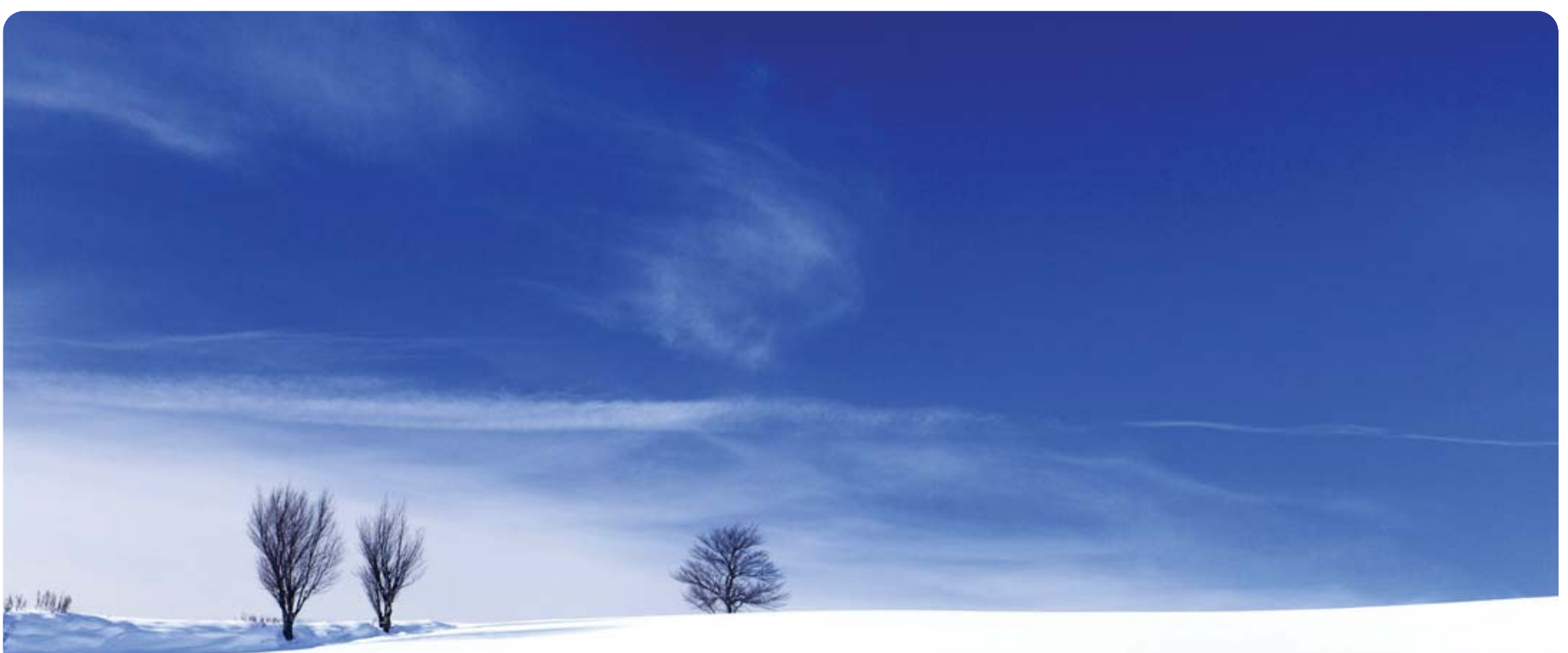

